\title{
A Brief History of Choline
}

\author{
Steven H. Zeisel \\ UNC Nutrition Research Institute, University of North Carolina at Chapel Hill, Kannapolis, N.C., USA
}

\section{Key Words}

Acetylcholine $\cdot$ Brain $\cdot$ Choline $\cdot$ Phosphatidylcholine

\begin{abstract}
In 1850, Theodore Gobley, working in Paris, described a substance, 'lecithine', which he named after the Greek 'lekithos' for egg yolk. Adolph Strecker noted in 1862 that when lecithin from bile was heated, it generated a new nitrogenous chemical that he named 'choline'. Three years later, Oscar Liebreich identified a new substance, 'neurine', in the brain. After a period of confusion, neurine and choline were found to be the same molecule, and the name choline was adapted. Lecithin was eventually characterized chemically as being phosphatidylcholine. In 1954, Eugene Kennedy described the cytidine 5-dihphosphocholine pathway by which choline is incorporated into phosphatidylcholine. A second route, the phosphatidylethanolamine- $N$-methyltransferase pathway, was identified by Jon Bremer and David Greenberg in 1960. The role of choline as part of the neurotransmitter acetylcholine was established by Otto Loewi and Henry Dale. Working in the 1930s at the University of Toronto, Charles Best showed that choline prevented fatty liver in dogs and rats. The importance of choline as an essential nutrient for human health was determined in the 1990s through controlled feeding studies in humans. Recently, an understanding of the role of genetic variation in setting the dietary requirement for choline in people is being unraveled.

Copyright $\odot 2012$ S. Karger AG, Basel
\end{abstract}

\section{KARGER}

Fax +4161306 1234

E-Mail karger@karger.ch

www.karger.com
(C) 2012 S. Karger AG, Basel

$0250-6807 / 12 / 0613-0254 \$ 38.00 / 0$

Accessible online at:

www.karger.com/anm

\section{The Discovery of Choline}

The middle of the 19th century was a period when scientists were avidly pursuing the chemical composition of living tissues. In 1850, Theodore Gobley (1911-1876) (fig. 1), a member of the Académie Nationale de Pharmacie, and a pharmacist in Paris, isolated a molecule from brain tissue and carp fish eggs that he described as 'matière phosphorée' which he named 'lecithine' from the Greek 'lekithos' (egg yolk) [1]. We now know that this phospholipid (in English called lecithin), is a constituent of most membranes. In 1862, Adolph Strecker (18221871) (fig. 2), recently having moved to the University of Tübingen as a Professor, was characterizing the composition of bile from pig and ox, and found that lecithin from bile, when boiled, generated a new nitrogenous chemical that Strecker named 'choline' [2]. The name was derived from the Greek word for bile - 'chole'. Eventually, lecithin was characterized chemically as being phosphatidylcholine [3].

Three years later, in 1865, Oscar Liebreich (1839-1908) (fig. 3) was completing the study of medicine in Königsberg, Tübingen, and Berlin. Working on human brain, Liebreich identified what he thought was 'the mothersubstance-of-all' which he named 'protagon'. He demonstrated that a constituent of protagon was a new molecule which he named 'neurine' [4]. Neurine was identical to a chemical previously synthesized in 1858 by treating trimethylamine and ethylene bromide. After a short period
Prof Steven $\mathrm{H}$. Zeisel, MD, PhD

UNC Nutrition Research Institute, University of North Carolina at Chapel Hill 500 Laureate Way

Kannapolis, NC 28081 (USA)

E-Mail Steven_Zeisel@unc.edu 


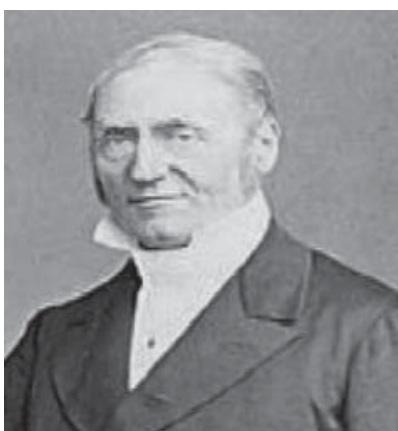

Fig. 1. Theodore Gobley.

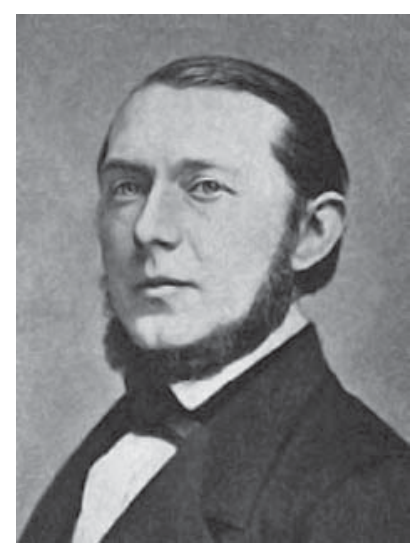

Fig. 2. Adolph Strecker.

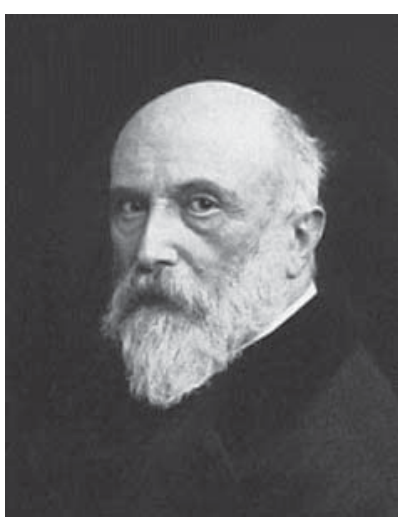

Fig. 3. Oscar Liebreich.

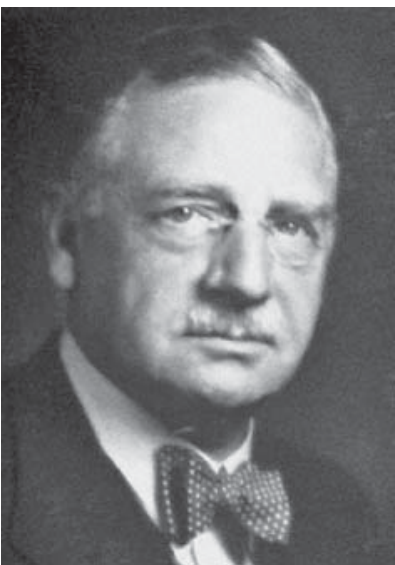

Fig. 4. Otto Loewi. of confusion, it was accepted that choline and neurine were the same molecule, and the name choline was adopted. The pathway whereby choline is incorporated into phosphatidylcholine remained unknown until 1954, when Eugene Kennedy (1919-2011), at the University of Chicago, described the cytidine 5-diphosphocholine pathway [5]. A second pathway for forming the choline component of phosphatidylcholine [the phosphatidylethanolamine- $N$-methyltransferase (PEMT) pathway] was identified by Jon Bremer and David Greenberg at the University of California School of Medicine, San Francisco, in 1960, and involved the methylation of phosphatidylethanolamine using $S$-adenosylmethionine [6].

\section{Choline's Function as Part of the Neurotransmitter Acetylcholine}

Before 1921, it was not known how nerves communicated with each other. Otto Loewi (1873-1961) (fig. 4), a physician and Professor at the University of Graz, Austria, found that when he stimulated the vagal nerve it secreted a substance he called 'vagusstoffe' [7]. Henry Dale (1875-1968) (fig. 5), working at the Wellcome Physiological Research Laboratories, had previously isolated a compound from fungi that produced effects when applied to organs that were similar to those produced by activating nerves; this compound contained a choline molecule and he named it acetylcholine. When Dale heard of Loewi's studies, he realized that the neurotransmitter Loewi called 'vagusstoffe' was the molecule acetylcholine [8]. Loewi and Dale shared the 1936 Nobel Prize for this work proving the chemical transmission of nervous impulses. Half a century later, interest in choline was stimulated when Prof. Richard Wurtman and his graduate student Edith Cohen at the Massachusetts Institute of Technology, and separately Dean Haubrich at the Squibb Institute for Medical Research, discovered that the rate of synthesis of the neurotransmitter acetylcholine could be modulated by changing dietary choline intake $[9,10]$. This discovery led to new therapeutic approaches for tardive dyskinesia (a movement disorder that is a side effect of neuroleptic drugs) [11].

\section{Choline as an Essential Nutrient}

It was appreciated that choline was a component of two biologically important molecules, phosphatidylcholine and acetylcholine, but it was not until 1932 that investigators uncovered the first evidence that choline might be an essential nutrient (needs could not be met by endogenous biosynthesis). During the summer of 1922, Charles Best (1899-1978), a medical student at the University of Toronto, was working as an assistant to Frederick Banting (1891-1941) when they discovered insulin (fig. 6). These studies used pancreatectomized dogs which developed fatty degeneration of the liver. After Best became Professor of Physiology at Toronto in 1929, he continued studies on these dogs and observed that this fatty liver could be corrected by feeding either raw pancreas or lecithin [12]. During the period 1932-1934, Best showed that choline was the active component of lecithin that prevented fatty liver in dogs and rats $[13,14]$. 
Fig. 5. Henry Dale.

Fig. 6. Charles Best (left) and Fredrick Banting (right) with one of the diabetic dogs used in the experiments with insulin. Courtesy of the University of Toronto Archives.
5

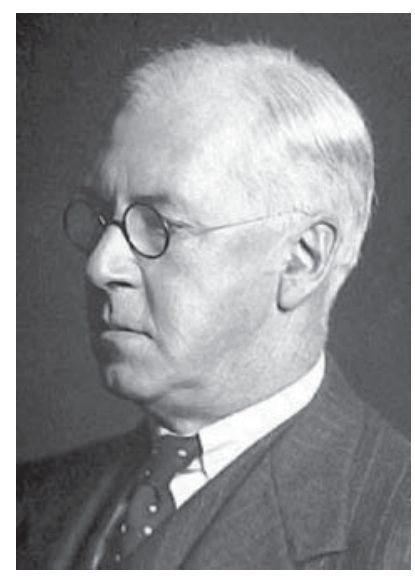

6

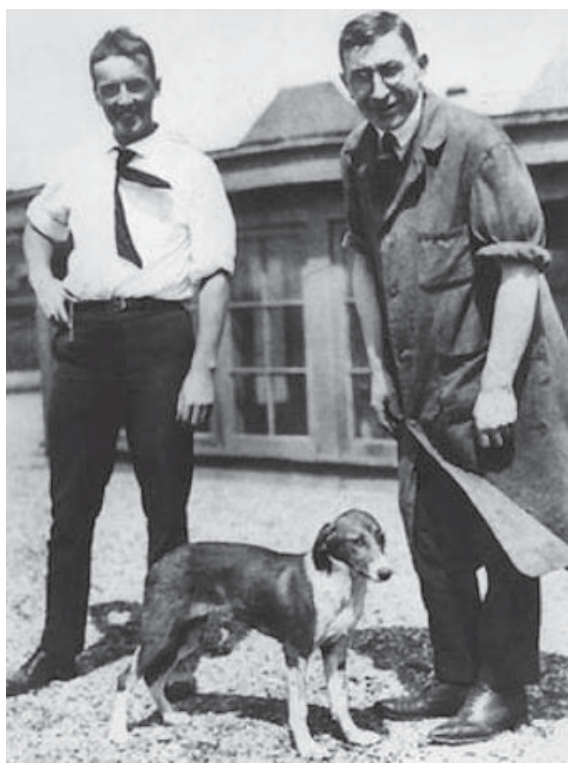

Interest in the nutrient functions of choline remained high through the 1940s. Dietary choline was found to prevent the bone disease 'perosis' that occurred in developing chickens [15]. In rats, choline deficiency was associated with atheromatous changes in aorta, carotid and coronary arteries [16]. Young rats deprived of choline developed hemorrhagic kidneys [17] and intraocular hemorrhages [18]. Studies were published describing choline deficiency in the rabbit, calf, guinea pig, hamster and baboon [19-23]. By the mid-1950s, investigators began to recognize that choline-deficient animals also developed liver cancers [24]. This led to a renewed interest in choline deficiency, along with deficiency of other methyl donors and the carcinogenic process [25-32]. Despite all of the animal findings on the effects of choline deficiency, scientists continued to believe that humans were different and did not need to eat choline. This remained accepted dogma for almost 5 decades.

\section{From Acetylcholine to Proving the Human Requirement for Choline}

In 1977, fresh from completing my residency training in pediatrics, I joined the Wurtman laboratory as a graduate student just as his work on choline and acetylcholine was unfolding (discussed earlier). By chance, I made the observation that blood choline concentrations were much higher in the neonate than in the adult [33]. In part, this was because mammary gland transports choline into milk, and neonates therefore are fed with a very rich source of choline [34, 35]. This was not always the case when infants were fed commercial infant formulas, as choline content could be much lower in some formulations [36]. Fortunately, in 2007, most commercial formulas were 'humanized' in terms of choline content. Working with a fellow student and long-term collaborator, Jan Blusztajn, we showed that the endogenous biosynthesis of phosphatidylcholine in brain and liver was increased in newborn rodents [37], contributing to the very high choline concentrations observed in newborns. Adding to this story of choline's importance in early life, others were describing how choline was concentrated across the placenta to be delivered to the fetus [38]. It seemed that the mother was designed to deliver large amounts of choline to the fetus and infant so as to sustain very high tissue concentrations of choline.

A wife-husband team of investigators at Columbia University (Christina Williams and Warren Meck) became aware of our research in choline and wondered whether high perinatal choline concentrations in brain might influence brain function by increasing acetylcholine release. They made the very important observation that the dietary availability of choline to the fetus and infant rat had major effects on performance on spatial maze tests, a hippocampal function [39]. They observed that enhancement of memory by extra choline lasted a lifetime. This fascinating observation led to a sustained effort by my research team, the Williams-Meck team and by Jan Blusztajn to determine the underlying mechanisms for 
this effect of choline. Among several potential mechanisms, we found that choline is an important epigenetic modifier (changes the methylation of DNA and histones), and that this modulated gene expression in brain resulting in enhanced neurogenesis in the hippocampus [40].

During the period of exploration of choline's role in brain development, I began to think about why choline was a required nutrient for so many species of animals, but was thought not to be required by humans (fig. 7). An interesting paper reported that patients fed with total parenteral nutrition solutions had diminished plasma choline concentrations [41] and was followed a few years later by a series of papers confirming this observation [42-44] and reporting that these people also developed fatty liver and liver dysfunction [45]. Total parenteral nutrition solutions contain little choline. It seemed obvious to me that sick humans, when deprived of choline, became choline deficient. Would this be true for healthy humans? Our research team set out to answer this question, and luckily chose to conduct the study in men (at that time the National Institutes of Health did not require that women be studied). In 1991, we reported that men fed defined diets low in choline content developed fatty liver and liver damage that resolved when choline was reinstated in the diet [46]. In subsequent studies that included women, we found that premenopausal women often did not develop organ dysfunction when deprived of dietary choline, and this was because estrogen induces the gene (PEMT) responsible for de novo biosynthesis of phosphatidylcholine in liver (phosphatidylcholine serves as a source for choline) $[47,48]$. The subpopulation of premenopausal women who did develop choline deficiency when fed a low-choline diet usually had a genetic variation (SNP) in PEMT that abrogated the estrogen responsiveness of this gene [47]. Despite the resistance to choline deficiency seen in young women, almost all men and postmenopausal women developed fatty liver, liver damage, and/or muscle damage when fed a low-choline diet,

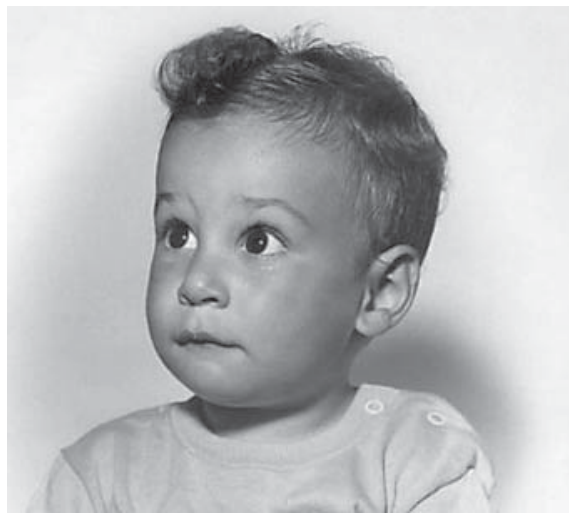

Fig. 7. Steven Zeisel, thinking about choline at an early age.

and this resolved when choline was restored in the diet [48]. The parenteral nutrition-choline story also advanced during this time period, and in 1995, Alan Buchman at Baylor College of Medicine observed that administering choline to patients fed by total parenteral nutrition prevented the development of fatty liver [49]. This body of evidence supported the conclusion that choline was an essential nutrient for men and postmenopausal women, and for some premenopausal women. In 1998, the scientific advisory panel considering recommendations for dietary reference intakes agreed that this was the case, and the Food and Nutrition Board of the US Institute of Medicine issued an Adequate Intake level recommendation for choline [50]. The line of investigation started in dogs by Charles Best in 1932 finally reached application in humans after 67 years.

\section{Acknowledgements}

This work was supported by grants from the US National Institutes of Health (DK55865 and DK56350).

\section{References}

1 Gobley T: Recherches chimiques sur les œufs de carpe. J Pharmacie Chim Paris 1850;17: 401.

2 Strecker A: Über einige neue Bestandtheile der Schweinegalle. Ann Chem Pharmacie 1862;183:964-965.

3 Gobley T: Sur la lécithine et la cérébrine. J Pharmacie Chim Paris 1874;19:346. $\checkmark 4$ Liebreich O: Ueber die chemische Beschaffenheit der Hirnsubstanz. Ann Chem Pharmacie 1865;134:29.

$\checkmark 5$ Kennedy EP: Synthesis of phosphatides in isolated mitochondria. II. Incorporation of choline into lecithin. J Biol Chem 1954;209: 525-535.

6 Bremer J, Greenberg DM: Biosynthesis of choline in vitro. Biochim Biophys Acta 1960; 37:173-175.
7 Loewi O: Über humorale Übertragbarkeit der Herznervenwirkung. Pflügers Archiv 1921;189:239-242.

$>8$ Dale $\mathrm{H}$ : The action of certain esters and ethers of choline and their relation to muscarine. J Pharm Exp Ther 1914;6:147-190.

9 Cohen EL, Wurtman RJ: Brain acetylcholine: control by dietary choline. Science 1976; 191:561-562. 
10 Haubrich DR, Wedeking PW, Wang PF: Increase in tissue concentration of acetylcholine in guinea pigs in vivo induced by administration of choline. Life Sci 1974;14:921-927.

-11 Growdon JH, Hirsch MJ, Wurtman RJ, Wiener W: Oral choline administration to patients with tardive dyskinesia. N Engl J Med 1977;297:524-527.

12 Hershey JM, Soskin S: Substitution of 'lecithin' for raw pancreas in a diet of depancreatized dog. Am J Physiol 1931;93:657-658.

-13 Best CH, Huntsman ME: Effect of choline on liver fat of rats in various states of nutrition. J Physiol 1935;83:255-274.

14 Best CH, Huntsman ME: The effects of the components of lecithine upon the deposition of fat in the liver. J Physiol 1932;75:405-412.

15 Jukes TH: The prevention of perosis by choline. J Biol Chem 1940;134:789-792.

- 16 Hartroft WS, Ridout JH, Sellers EA, Best CH: Atheromatous changes in aorta, carotid and coronary arteries of choline-deficient rats. Proc Soc Exp Biol Med 1952;81:384-393.

17 Griffith WH, Wade NJ: The occurrence and prevention of hemorrhagic degeneration in young rats on a low choline diet. J Biol Chem 1939;131:567-573.

18 Bellows JG, Chinn H: Intraocular hemorrhages in choline deficiency. Arch Ophthalmol 1943;30:105-109.

$\checkmark 19$ Hove E, Copeland D, Salmon W: Choline deficiency in the rabbit. J Nutr 1954;53:377389.

20 Johnson BC, Mitchell HH, Pinkos JA: Choline deficiency in the calf. J Nutr 1951;43:3748.

-21 Handler P, Bernheim F: Choline deficiency in the hamster. Proc Soc Exp Med 1949;72: 569.

22 Casselman WGB, Williams GR: Choline deficiency in the guinea pig. Nature 1954;173: 210-211.

-23 Hoffbauer FW, Zaki FG: Choline deficiency in the baboon and rat compared. Arch Path 1965;79:364-369.

-24 Salmon WD, Copeland DH: Liver carcinoma and related lesions in chronic choline deficiency. Ann NY Acad Sci 1954;57:664-677.

25 Newberne PM, Ahlstrom A, Rogers AE: Effects of maternal dietary lipotropes on prenatal and neonatal rats. J Nutr 1970;100: 1089-1097.

26 Johnson AR, Lao S, Wang T, Galanko JA, Zeisel SH: Choline dehydrogenase polymorphism rs12676 is a functional variation and is associated with changes in human sperm cell function. PLoS One 2012;7:e36047.
27 Newberne PM, Rogers AE: Labile methyl groups and the promotion of cancer. Ann Rev Nutr 1986;6:407-432.

28 Ghoshal AK, Ahluwalia M, Farber E: The rapid induction of liver cell death in rats fed a choline-deficient methionine-low diet. Am J Pathol 1983;113:309-314.

29 Rogers AE, Newberne PM: Lipotrope deficiency in experimental carcinogenesis. Nutr Cancer 1980;2:104-112.

30 Lombardi B, Shinozuka H: Enhancement of 2 -acetylaminofluorene liver carcinogenesis in rats fed a choline-devoid diet. Int J Cancer 1979;23:565-570.

31 Shinozuka H, Sells MA, Katyal SL, Sell S, Lombardi B: Effects of a choline-devoid diet on the emergence of gamma-glutamyltranspeptidase-positive foci in the liver of carcinogen-treated rats. Cancer Res 1979;39:25152521.

32 Rogers AE: Reduction of N-nitrosodiethylamine carcinogenesis in rats by lipotrope or amino acid supplementation of a marginally deficient diet. Cancer Res 1977;37:194-199.

33 Zeisel SH, Epstein MF, Wurtman RJ: Elevated choline concentration in neonatal plasma. Life Sci 1980;26:1827-1831.

34 Chao CK, Pomfret EA, Zeisel SH: Uptake of choline by rat mammary-gland epithelial cells. Biochem J 1988;254:33-38.

35 Yang EK, Blusztajn JK, Pomfret EA, Zeisel $\mathrm{SH}$ : Rat and human mammary tissue can synthesize choline moiety via the methylation of phosphatidylethanolamine. Biochem J 1988;256:821-828.

- 36 Holmes-McNary M, Cheng WL, Mar MH, Fussell S, Zeisel SH: Choline and choline esters in human and rat milk and infant formulas. Am J Clin Nutr 1996;64:572-576.

37 Blusztajn JK, Zeisel SH, Wurtman RJ: Synthesis of lecithin (phosphatidylcholine) from phosphatidylethanolamine in bovine brain. Brain Res 1979;179:319-327.

38 Sweiry JH, Yudilevich DL: Characterization of choline transport at maternal and fetal interfaces of the perfused guinea-pig placenta. J Physiol 1985;366:251-266.

39 Meck WH, Smith RA, Williams CL: Pre- and postnatal choline supplementation produces long-term facilitation of spatial memory. Dev Psychobiol 1988;21:339-353.
40 Albright CD, Friedrich CB, Brown EC, Mar $\mathrm{MH}$, Zeisel SH: Maternal dietary choline availability alters mitosis, apoptosis and the localization of TOAD-64 protein in the developing fetal rat septum. Brain Res 1999; 115:123-129.

-41 Burt ME, Hanin I, Brennan MF: Choline deficiency associated with total parenteral nutrition. Lancet 1980;2:638-639.

42 Sheard NF, Tayek JA, Bistrian BR, Blackburn GL, Zeisel SH: Plasma choline concentration in humans fed parenterally. Am J Clin Nutr 1986;43:219-224.

43 Chawla RK, Berry CJ, Kutner MH, Rudman D: Plasma concentrations of transsulfuration pathway products during nasoenteral and intravenous hyperalimentation of malnourished patients. Am J Clin Nutr 1985;42: 577-584.

-44 Hall RI, Ross LH, Bozovic MG, Grant JP: The effect of choline supplementation on hepatic steatosis in the parenterally fed rat. J Parent Ent Nutr 1985;9:597-599.

-45 Tayek JA, Bistrian B, Sheard NF, Zeisel SH, Blackburn GL: Abnormal liver function in malnourished patients receiving total parenteral nutrition: a prospective randomized study. J Am Coll Nutr 1990;9:76-83.

46 Zeisel SH, daCosta KA, Franklin PD, Alexander EA, Lamont JT, Sheard NF, Beiser A: Choline, an essential nutrient for humans. FASEB J 1991;5:2093-2098.

47 Resseguie ME, da Costa KA, Galanko JA, Patel M, Davis IJ, Zeisel SH: Aberrant estrogen regulation of PEMT results in choline deficiency-associated liver dysfunction. J Biol Chem 2011;28:1649-1658.

48 Fischer LM, daCosta, K, Kwock L, Stewart P, Lu TS, Stabler S, Allen R, Zeisel S: Sex and menopausal status influence human dietary requirements for the nutrient choline. Am J Clin Nutr 2007;85:1275-1285.

49 Buchman A, Dubin M, Moukarzel A, Jenden D, Roch M, Rice K, Gornbein J, Ament M: Choline deficiency: a cause of hepatic steatosis during parenteral nutrition that can be reversed with intravenous choline supplementation. Hepatology 1995;22:1399-1403.

50 Institute of Medicine, and National Academy of Sciences USA: Choline; in Dietary Reference Intakes for Folate, Thiamin, Riboflavin, Niacin, Vitamin B12, Pantothenic Acid, Biotin, and Choline, vol 1. National Academy Press, Washington, DC, 1998, pp 390 422. 